\title{
Private Sector Investment in Agricultural Research in Pakistan
}

\begin{abstract}
Mumtaz Ahmad and Joseph G. NAGY
Private sector investment in agricultural research in Pakistan, although growing in importance, is limited at present and with a few exceptions, has not had a significant impact on agricultural production and productivity. The publicly funded agricultural research system has made the major contribution to increases in production and productivity growth. However the impressive gains of the past cannot be achieved with the current underfunded public research system which makes it all the more important for private sector investment in agricultural research to achieve its full potential in areas of its comparative advantage. This paper identifies the magnitude of private sector agricultural research investment in Pakistan and discusses some of the current policy constraints that hamper its scope. Information was gathered through informal and formal surveys of multinational and national firms conducting agricultural research in Pakistan in the areas of inputs and product processing. Although private sector investment in agricultural research has more than doubled in the past ten years, uncertainty persists surrounding privatisation issues, unresolved intellectual property rights regulation, and the enforcement of seed certification and truth-in-labelling rules and regulations.
\end{abstract}

\section{INTRODUCTION}

Agriculture remains Pakistan's largest single sector of the economy. The importance of the agricultural sector in terms of food security and foreign exchange earnings cannot be overstated. Past growth in agricultural production has been impressive, especially during the green revolution between the years 1960 and 1970. However, production and productivity increases in the future may not be sustainable at the same level as in the past [Nagy and Quddus (1998 and 1998a)]. Most food supply and demand projections for Pakistan forecast large agricultural imports if the investment in the agricultural sector and particularly in research remains at its current low levels [Rosegrant et al. (1995)].

Mumtaz Ahmad is an International Agricultural Consultant, Islamabad, Pakistan and Joseph G. Nagy is an International Consultant in Agricultural and Applied Economics, Project Planning, Appraisal, and Management, Saskatoon, Saskatchewan, Canada.

Authors' Note: The authors would like to acknowledge the contributions made by Dr C. E. Pray, Professor, Department of Agriculture, Food and Resource Economics, Rutgers, The State University of New Jersey and by Dr Zahur Alam, EDC, Islamabad. This study is part of a larger study of private sector and international agricultural technology transfer in developing countries by Pray and Fuglie and is sponsored by USDA. 
The public sector has provided most of the investment in agricultural research in Pakistan to-date. However, it is underfunded at present and is not capable of appreciably increasing productivity in the near future. Most of the research funding goes into maintenance research with little prospect for increasing yields and animal productivity above present levels [Nagy and Quddus (1998 and 1998a)].

The increase in private agricultural research in the world in the past decade suggests that the private sector in Pakistan should also make larger contribution to overall agricultural research. However, the country's political and economic climate coupled with problems like unresolved intellectual property rights and enforcement of regulations has dampened the considerable potential that private sector agricultural research could have had in Pakistan. Some growth there has been though. Private sector investment in agricultural research has more than doubled in the last ten years but remains at about onefifth of public sector expenditure which itself is at a very low level.

This paper presents a study of private sector investment in agricultural research in Pakistan with the objective to: (1) identify the magnitude and scope of private sector agricultural research in Pakistan, and (2) identify current policy and technical constraints that mar its potential in Pakistan.

Information for the study is based on personal contact with secondary sources and on a survey questionnaire. Relevant government agencies, key informants, and private sector companies were contacted and informally asked questions pertaining to private sector research. A formal survey was conducted of private sector companies that provide agricultural inputs and those that process agricultural commodities. The formal survey questionnaire was sent in May, 1998 to firms in Pakistan that were identified as either currently doing private sector agricultural research, had done research in the past, or had the potential to undertake private research.

The current study follows two previous studies done in 1987 by Ahmad (1987) and by Pray (1987). Some of the results of the current study are compared to the two earlier studies. The current study is an update to the Ahmad (1987) study but also includes the changes that have occurred since 1987 in terms of impact and changes in policy towards private sector research.

Section 2 discusses the past and present private sector investment and research environment. Section 3 discusses the results of the formal survey and identifies trends that occurred since the two 1987 surveys. Section 4 presents a discussion on the structure and research investment in the seed, fertiliser, and plant protection agricultural input industries in Pakistan. Section 5 presents some concluding comments.

\section{THE PRIVATE SECTOR INVESTMENT AND RESEARCH ENVIRONMENT}

Agricultural research remained an almost exclusive domain of the public sector until the 1980s. The role of the private sector remained limited before this 
time. The private sector underwent a trying period of time from 1972 to 1976. Along with large and medium sized private sector industries, many agribusiness firms were nationalised and merged under various state-owned corporations that controlled the processing and export of agricultural products. This continued into the early 1980s when the nationalisation process was reversed and a slow beginning towards denationalisation and deregulation of agriculture and agricultural industries and parastatals began.

The privatisation process began in earnest in 1988 when the government of the day initiated the privatisation of many industries and took a more supportive view of private sector investment. This policy continues with privatisation and the disbanding of parastatals and programmes and policies to stimulate private sector investment. Steps have been taken, for example, to phase out the upper ceiling on land holdings by agricultural companies and programmes have been put into place for easier access to credit. During the period from 1988 to 1998, most subsidiaries of the Ghee Corporation of Pakistan, the Pakistan Industrial Development Corporation, and the National Fertiliser Corporation were privatised. Other parastatals such as the Trading Corporation of Pakistan, the Rice Export Corporation, and the Cotton Export Corporation were downsized and merged with the Trading Corporation. The Marketing and Storage Corporation was disbanded. Other parastatals, including the Trading Corporation, have been exposed to competition with the private sector.

Government policies toward agriculture have not been favourable [World Bank (1994)]. Policies have kept farm level prices of the three major crops of wheat, cotton and rice at lower than free market prices thereby decreasing farm level profit margins. This can only hurt private sector agribusiness investment as optimum input levels are lower than they would be under higher prices and wider farm level profit margins from a free market. Farm level profit margins were further squeezed with the removal of the subsidies on fertiliser and credit.

Intellectual property rights are still in the process of being finalised and regulated by the government. Pakistan's Plant Breeders Rights Act drafted by the Federal Seed Certification Department in 1996 and vetted by the Geneva-based International Union of Plant Variety Protection (UPOV) has yet to become law. Pakistan, as a member of the World Trade Organisation and a signatory to the Trade Related Intellectual Property Rights System (TRIPS) is committed to introduce legislation in the form of plant breeders rights or a patent by January 1, 2000. At present, new open-pollinated varieties of crops developed by both the public and private sector are not patented and continue to be available for multiplication and sale by both public and private sector agribusiness firms without restriction or paying royalties to breeders or public sector institutions. This has kept the multinationals from introducing many open-pollinated varieties with superior germplasm. Seed firms, however, can register all new varieties in Pakistan with the Federal Seed Certification Department, but many national firms do not use the registry. There is also 
a ten year internationally sanctioned exemption of new varieties imported into Pakistan from other countries to the year 2005. Other agriculturally related innovations can and are being registered with the Patent Office which now resides in the Ministry of Industries or the trade marks registry within the Ministry of Commerce.

What may be of greater concern in the future for private sector investment in agricultural research is the enforcement of plant breeders rights, patent regulations, and seed certification and truth-in-labelling laws. Once plant breeders rights become law, enforcement becomes an issue. Enforcement of truth-in-labelling lawslabelling and identifying seed as being of a certain quality and pedigree-is a major problem [Alam and Saleemi (1996)]. The Federal Seed Certification Department do not have the number of trained staff required to properly monitor seed certification and truth-in-labelling regulations. Seeds can be imported without being tested in Pakistan as to their authenticity and local seed can easily be mixed with good quality or an improved variety seed without much enforcement of the seed certification act. Past experience with enforcing the laws pertaining to weights and measures and the adulteration of agricultural chemicals, particularly fertilisers, pesticides and herbicides, has also not been very good. This creates an environment of mistrust among farmers who are reluctant to pay high prices for agricultural inputs which may be adulterated or of poor quality.

At the moment, the cotton industry is the largest user of farm level inputs. Fertiliser, pesticides and cotton seed are in demand by cotton farmers and have been targeted by private sector research. In particular, good quality and improved cotton seed is in high demand because of the cotton leaf curl virus problem. Seed companies obtain their highest returns on new cotton seed varieties but make little money on open pollinated wheat or maize varieties. Competition is still very strong from the new wheat and maize varieties coming from the public sector research system (supported by CIMMYT and other International Agricultural Research Centres) and distributed by the Punjab and Sindh Seed Corporations.

The private sector investment and research environment in the 1990s has been the best it has been since the nationalisation policies in the 1970s. Official government policy was one of continued privatisation, deregulation and trade liberalisation and the creation of an environment for the expansion of the role of the private sector in agriculture, agribusiness and research. However, the mood of most private investors in agribusiness is cautious, particularly for research that has a longterm pay-off. There is both political and financial instability within the country. Despite the political change that brought in a fledgling democracy in late 1988, there have been five interim governments between four regularly elected governments. The country's foreign exchange reserves have been chronically low as have been the government's financial resources to pay for both domestic and foreign debt. Further uncertainty is generated by ongoing developments on Pakistan's borders. These 
uncertainties have led to cautious private sector investment and private sector research programmes that can be characterised as short-term adaptive research based on technology transfer opportunities. Thus while the current government policy is amenable to private sector investment, other factors hold the private sector back. Investors still remember the nationalisation period of the 1970s.

\section{OVERVIEW OF PRIVATE SECTOR RESEARCH INVESTMENT}

\section{The Formal Survey}

A formal survey was conducted of firms in the agriculture sector that provide inputs to farmers and to those firms processing agricultural products. The formal survey questionnaire was sent in May, 1998 to 362 firms in Pakistan that were identified as either currently doing private sector agricultural research, had done research in the past or had the potential to undertake private research. Of the firms surveyed, 244 primarily produced or manufactured agricultural inputs to be used at the farm level and 118 were predominantly processing firms. However, tobacco companies do both but spend about 80 percent of their research effort on the agricultural inputs side. The list of firms was based on the Ahmad (1987) survey list updated by information from all 31 Chambers of Commerce and Industries in Pakistan as well as from Agribusiness Trade Associations. Questions were asked about: (1) the area and type of research undertaken, (2) the number of scientists employed by qualification and number of technicians and field staff, (3) research expenditures, (4) support and collaboration with public research institutions, and (5) major constraints to doing research.

Of the 362 firms surveyed, 159 firms (44 percent) responded to the survey questionnaire. Table 1 presents the number of questionnaires sent and the number of responses by agribusiness category. The categories are divided into: (1) firms that provide or do research on agricultural inputs, and (2) firms that primarily process agricultural products. Each category is further divided by their identity as a multinational firm or a national firm. Most of the firms that did not initially reply were contacted personally or by telephone. This elicited more responses but also indicated that in the final analysis, the majority of the firms that did not respond to the questionnaire did little or no research. Many firms are registered but not all firms are active. For example, there are over 100 national seed firms registered in Pakistan but only a few are active and fewer still actually do research [Alam and Saleemi (1996)]. Information from the survey and from personal contacts indicated that there were about 170 firms actively undertaking some form of research. Thus, the 159 firms that did respond to the survey undertake some research and make up about 95 percent of all firms that undertake private sector agricultural research in Pakistan. 
Table 1

Survey Questionnaires Sent and Received and Areas of Research

\begin{tabular}{|c|c|c|c|}
\hline Agribusiness Category & $\begin{array}{l}\text { Number } \\
\text { Surveyed }\end{array}$ & $\begin{array}{l}\text { Number of } \\
\text { Responses }\end{array}$ & Description of Research \\
\hline \multicolumn{4}{|l|}{ A. Firms Providing Agricultural Inputs } \\
\hline \multicolumn{4}{|l|}{ 1. Multinational Firms } \\
\hline Agricultural Machinery & 2 & 1 & Manufacturing parts locally \\
\hline Fertiliser & 3 & 3 & Agronomic field trials \\
\hline Pesticide & 5 & 3 & Field trials/IPM \\
\hline Seed & 4 & 2 & $\begin{array}{l}\text { Variety and hybrid evaluation } \\
\text { trials }\end{array}$ \\
\hline Tobacco & 2 & 2 & Agronomic trials \\
\hline Sub-total & 16 & 11 & \\
\hline \multicolumn{4}{|l|}{ 2. National Firms } \\
\hline Agricultural Machinery & 98 & 34 & Adapting imported machinery \\
\hline Fertiliser & 2 & 2 & Agronomic field trials \\
\hline Poultry/Livestock Feed & 21 & 5 & Feed ingredient substitutes \\
\hline Poultry & 8 & 6 & Husbandry, new breeds \\
\hline Pesticides & 21 & 12 & Agronomic trials \\
\hline Planting Material/Tissue Culture & 8 & 1 & $\begin{array}{l}\text { Virus free potato, dates and } \\
\text { banana }\end{array}$ \\
\hline Seed & 70 & 26 & New variety trials (hybrids) \\
\hline Sub-total & 228 & 86 & \\
\hline \multicolumn{4}{|c|}{ B. Agricultural Product Processing Firms } \\
\hline \multicolumn{4}{|l|}{ 1. Multinational Firms } \\
\hline Dairy and Dairy Products & 1 & 1 & $\begin{array}{l}\text { Developing products to local } \\
\text { taste }\end{array}$ \\
\hline Tobacco & a & a & Processing and curing trials \\
\hline \multicolumn{4}{|l|}{ 2. National Firms } \\
\hline Dairy and Dairy Products & 5 & 2 & $\begin{array}{l}\text { Product and processing } \\
\text { development }\end{array}$ \\
\hline Food Processing & 32 & 22 & Product development \\
\hline Herbal Medicines & 16 & 2 & Product development \\
\hline Maize Products & 2 & 2 & $\begin{array}{l}\text { Starch, edible oil, starch based } \\
\text { sugars }\end{array}$ \\
\hline Sugar (Cane) & 35 & 17 & $\begin{array}{l}\text { By-product development } \\
\text { (molasses, Alcohol, bio- } \\
\text { fertiliser), new varieties }\end{array}$ \\
\hline Solvent Oil Extractor & 9 & 5 & $\begin{array}{l}\text { Processing, new oilseed crops } \\
\text { (canola) }\end{array}$ \\
\hline Vegetable Ghee & 18 & 11 & Alternative blending formulas \\
\hline Sub-total & 117 & 61 & \\
\hline Total & 362 & 159 & \\
\hline
\end{tabular}

${ }^{\mathrm{a}}$ The same Tobacco Companies as in A.1. 


\section{Private Sector Research Areas}

Table 1 also gives a brief description of the type of research being done in each category. The agribusiness categories in Table 1 are similar to the Ahmad (1987) survey categories with the exception of the addition of herbal medicines and planting material/tissue culture which are new areas of private sector research. Research varies from simple adaptive research that most national agricultural machinery firms do to technologically advanced research as in the case of planting and tissue culture research. All the respondents indicated that they did adaptive research (adjusting technology to local conditions). All the multinational firms indicated that some of their research could also be classified as applied research (new technology creation) but only 5 percent of national firms said they did applied research. The national firms included the planting material and tissue culture firms and several firms from the seed and sugar categories. Thus most private sector research can be described as adaptive and most research is carried on as an adjunct activity to the main business of selling an input or processed product.

\section{Number of Scientists and Staff by Qualification}

All 159 respondents answered the question on scientist and staff numbers (Table 2). Of the total 292 scientists reported, 4.5 percent, 31 percent, and 64.5 percent are qualified having Ph.D., MSc. and B.Sc. degrees respectively. In comparison, the breakdown for the same qualification categories in the Pakistan public agricultural research sector is 9.5 percent, 63.5 percent and 27 percent [PARC (1997)]. The Ahmad (1987) survey reported 3.5 percent, 45 percent and 51.5 percent for the same categories respectively indicating a slight shift toward the use of more B.Sc. qualified scientists in place of scientists with an MSc. Multinational firms employ more scientists per firm (7.3 per firm) than national firms (1.38 per firm). Multinational firms also hire more qualified scientists per firm. For example, multinationals hire more Ph.D's per firm (0.5 per firm) than national firms (about 0.05 per firm). However, comparisons with the Ahmad (1987) survey indicate that tobacco firms had two Ph.D.'s in 1987 but today have none. Discussions with the tobacco and other firms indicate that they can do most of their adaptive research using well qualified MSc. and B.Sc. trained scientists. Also, they say it is more difficult now to employ well trained Ph.D. scientists. Reasons put forward are that Ph.D's now have more and better opportunities with Pakistan pharmaceuticals industries. Also, those Ph.D.'s that are trained abroad usually stay abroad.

There are about two technicians and field staff to support each scientist overall. This 2:1 ratio holds true for both multinational and national firm categories when taken separately. However, the category of firms providing agricultural inputs has about a 2.2:1 ratio whereas the agricultural product processing firms category has a 1.6:1 ratio. This compares with only a $0.4: 1$ support staff per research scientist 
Table 2

Number of Technicians and Field Staff and Scientists by Qualification

\begin{tabular}{|c|c|c|c|c|c|}
\hline \multirow[b]{2}{*}{ Agribusiness Category } & \multirow{2}{*}{$\begin{array}{l}\text { Technicians and } \\
\text { Field Staff }\end{array}$} & \multicolumn{4}{|c|}{ Number of Scientists } \\
\hline & & Ph.D. & MSc. & B.Sc. & Total \\
\hline \multicolumn{6}{|l|}{ A. Firms Providing Agricultural Inputs } \\
\hline \multicolumn{6}{|l|}{ 1. Multinational Firms } \\
\hline Agricultural Machinery & 23 & 0 & 1 & 6 & 7 \\
\hline Fertiliser & 21 & 2 & 5 & 13 & 20 \\
\hline Pesticide & 81 & 1 & 8 & 14 & 23 \\
\hline Seed & 16 & 3 & 3 & 4 & 10 \\
\hline Tobacco & 14 & 0 & 6 & 8 & 14 \\
\hline Sub-total & 155 & 6 & 23 & 45 & 74 \\
\hline \multicolumn{6}{|l|}{ 2. National Firms } \\
\hline Agricultural Machinery & 42 & 0 & 4 & 11 & 15 \\
\hline Fertiliser & 21 & 0 & 9 & 4 & 13 \\
\hline Poultry/Livestock Feed & 18 & 0 & 4 & 14 & 18 \\
\hline Poultry & 86 & 1 & 6 & 12 & 19 \\
\hline Pesticides & 26 & 1 & 3 & 17 & 21 \\
\hline Planting Material/Tissue Culture & 2 & 1 & 3 & 3 & 7 \\
\hline Seed & 48 & 0 & 3 & 11 & 14 \\
\hline Sub-total & 243 & 3 & 32 & 72 & 107 \\
\hline \multicolumn{6}{|c|}{ B. Agricultural Product Processing Firms } \\
\hline \multicolumn{6}{|l|}{ 1. Multinational } \\
\hline Dairy and Dairy Products & 18 & 0 & 3 & 7 & 10 \\
\hline Tobacco & 4 & 0 & 2 & 2 & 4 \\
\hline Sub-total & 22 & 0 & 5 & 9 & 14 \\
\hline \multicolumn{6}{|l|}{ 2. National } \\
\hline Dairy and Dairy Products & 18 & 1 & 5 & 7 & 13 \\
\hline Food Processing & 26 & 1 & 7 & 8 & 16 \\
\hline Herbal Medicines & 4 & 0 & 6 & 2 & 8 \\
\hline Maize Products & 9 & 0 & 2 & 6 & 8 \\
\hline Sugar & 59 & 2 & 11 & 27 & 40 \\
\hline Solvent Oil Extractor & 11 & 0 & - & 3 & 3 \\
\hline Vegetable Ghee & 28 & 0 & - & 9 & 9 \\
\hline Sub-total & 155 & 4 & 31 & 62 & 97 \\
\hline Total & 575 & 13 & 91 & 188 & 292 \\
\hline
\end{tabular}


ratio in Pakistan's public agricultural research sector indicating that the private sector has better support for its scientists [PARC (1997)].

\section{Private Sector Investment in Agricultural Research}

The survey questionnaire asked firms about their research expenditures. Although some firms responded, few firms gave complete information. It was decided to estimate research expenditures based on staff costs of technicians, field staff and scientists supplemented by partial information from survey results and information gathered through personal contacts with some leading firms. Average staff costs to firms for a Ph.D., MSc., B.Sc. and for technical and field staff were estimated to be Rs 60,000 , Rs 30,000 , Rs 15,000 , and Rs 7,500 per month respectively. The market for qualified scientists and staff is very competitive and multinational companies pay the same rates as nationals. From the information provided by the firms, operating costs were estimated to be equal to the sum of total staff costs. Operating costs include management costs, materials and office supplies, laboratory supplies, travel and daily allowances, repair and maintenance, utilities, petrol, oil and lubricants, communications, rent, taxes, and daily paid labour. No attempt was made to estimate capital costs of research.

Table 3 presents the estimate of staff and operating costs for private sector research in Pakistan for 1998. The cost per staff category, as presented above, were multiplied by the number of technicians and field staff and number of scientists in each staff category from Table 5 and doubled to account for operating costs. Total estimated costs are in the order of Rs 255 million (USD 5.7 million). As previously discussed, this estimate would include close to 95 percent of all staff and operating expenditures on private sector agricultural research in Pakistan.

In monetary terms, firms that produce or manufacture agricultural inputs account for two-thirds of private sector agricultural research and agricultural processing firms for one-third. Agricultural chemical research (fertilisers and pesticides) account for 41 percent of agricultural input research expenditures. The sugar industry accounts for 35 percent of agricultural processing expenditures. Multinational firms account for one-third and national firms for two-thirds of research expenditures. Of the multinational firms, pesticide firms spend the most on research and spend almost double that of fertiliser, the next highest category of firms in terms of expenditures. Poultry and sugar firms spend the most on research within the national firm category.

Pray (1987) estimated 1987 staff and operating costs to be at least a minimum of Rs 20 million. The Ahmad (1987) survey estimated 1987 research expenditures for staff and operating costs to be Rs 37 million when the same firm categories are included as in the 1998 survey. The Pray (1987) estimates were from direct personal contact with firms and thus the expenditure data is very credible for the firms that 
Table 3

Pakistan Private Sector Agricultural Research Expenditure Estimates, 1998

\begin{tabular}{|c|c|c|c|c|}
\hline \multirow[b]{2}{*}{ Agribusiness Category } & \multicolumn{4}{|c|}{ Research Expenditures (Million Rupees) } \\
\hline & Scientists & $\begin{array}{l}\text { Technicians } \\
\text { Field Staff }\end{array}$ & Total $^{1}$ & $\begin{array}{l}\text { Total } \\
\text { USD }^{2}\end{array}$ \\
\hline \multicolumn{5}{|l|}{ A. Firms Providing Agricultural Inputs } \\
\hline \multicolumn{5}{|l|}{ 1. Multinational Firms } \\
\hline Agricultural Machinery & 1.44 & 2.07 & 7.02 & 156,000 \\
\hline Fertiliser & 5.58 & 1.89 & 14.94 & 332,000 \\
\hline Pesticide & 6.12 & 7.29 & 26.82 & 596,000 \\
\hline Seed & 3.96 & 1.44 & 10.80 & 240,000 \\
\hline Tobacco & 3.60 & 1.26 & 9.72 & 216,000 \\
\hline Sub-total & 20.70 & 13.95 & 69.30 & $\$ 1,540,000$ \\
\hline \multicolumn{5}{|l|}{ 2. National Firms } \\
\hline Agricultural Machinery & 3.42 & 3.78 & 14.4 & 320,000 \\
\hline Fertiliser & 3.96 & 1.89 & 11.70 & 260,000 \\
\hline Poultry/Livestock Feed & 3.96 & 1.62 & 11.16 & 248,000 \\
\hline Poultry & 5.04 & 7.74 & 25.56 & 568,000 \\
\hline Pesticides & 4.86 & 2.34 & 14.40 & 320,000 \\
\hline Planting Material/Tissue Culture & 2.34 & 0.18 & 5.04 & 112,000 \\
\hline Seed & 3.06 & 4.32 & 14.76 & 328,000 \\
\hline Sub-total & 26.64 & 21.87 & 97.02 & $\$ 2,156,000$ \\
\hline \multicolumn{5}{|c|}{ B. Agricultural Product Processing Firms } \\
\hline \multicolumn{5}{|l|}{ 1. Multinational } \\
\hline Dairy and Dairy Products & 2.34 & 1.62 & 7.92 & 176,000 \\
\hline Tobacco & 1.08 & 0.36 & 2.88 & 64,000 \\
\hline Sub-total & 3.42 & 1.98 & 10.80 & $\$ 240,000$ \\
\hline \multicolumn{5}{|l|}{ 2. National Firms } \\
\hline Dairy and Dairy Products & 3.78 & 1.62 & 10.8 & 240,000 \\
\hline Food Processing & 4.60 & 2.34 & 13.88 & 308,444 \\
\hline Herbal Medicines & 2.52 & 0.36 & 5.76 & 128,000 \\
\hline Maize Products & 1.80 & 0.81 & 5.22 & 116,000 \\
\hline Sugar & 10.26 & 5.31 & 31.14 & 692,000 \\
\hline Solvent Oil Extractor & 0.54 & 0.99 & 3.06 & 68,000 \\
\hline Vegetable Ghee & 1.62 & 2.52 & 8.28 & 184,000 \\
\hline Sub-total & 25.12 & 13.95 & 78.14 & $\$ 1,736,444$ \\
\hline Total & 75.88 & 51.75 & 255.26 & $\$ 5,672,444$ \\
\hline
\end{tabular}

${ }^{1}$ Estimated expenditure for scientific manpower plus the total estimated expenditure for technicians and field staff multiplied by two to account for operating costs.

${ }^{2}$ One USD exchanged for 45 Rupees at the time of the survey in May/June, 1998. 
were contacted. However, the Ahmad (1987) survey cast a wider net and included more firms in the food processing and sugar industries. Using the Pakistan general consumers price index [Pakistan (1997)] to inflate 1987 Rupees to today's terms, Rs 37 million are equivalent to about Rs 100 million in 1998 rupees. Thus the 1998 expenditure estimate of Rs 255 million from Table 6 is about 2.5 times the 1987 estimate. This indicates that the growth in private sector agricultural research in Pakistan over the last ten years has more than doubled which is an encouraging trend but the amount spent is ridiculously small given the large agricultural sector and its importance to the economy of Pakistan. An expenditure of between USD 5 and 6 million is very small even if one considers that staff costs are one-half to one-quarter of the costs of similar quality staff in developed countries. Private research expenditure is thus about one-fifth of Pakistan's total expenditure of about USD 25 million per year on public agricultural research.

\section{Collaboration with Public Agricultural Research Institutions}

The survey results indicated that there was no working relationship between 61 percent of all private sector agricultural research firms and Pakistan's public sector research system (Table 4). Only 18 percent of the firms indicated that they had active support and collaborated with public sector researchers while 21 percent said they had some collaboration. The interaction was greater among multinational firms with over 90 percent of the firms indicating either some or active support and collaboration while the corresponding figure for national firms was only 35 percent. Among multi-nationals the agricultural machinery firms were the only firms with no interaction which was the ease with the majority (88 percent) of national firms. Among the national processing firms, the majority of food processing, sugar, and vegetable ghee firms had no link. Collaboration was in the form of general information flow and information on the latest research methodologies and techniques. Some firms hired public sector researchers as short-term consultants and collaborative research was also done. One milk/dairy firm and two fertiliser firms indicated that they sponsored research projects at public research institutions. The Fauji Fertiliser Company and some national fertiliser companies sponsored MSc. degrees at Pakistan's three main agricultural universities in soil science and agronomy.

There was also some collaboration with the Agribusiness Directorate within PARC [Nagy and Ali (1996)]. Their mandate was to actively promote the commercialisation of agriculturally related technologies developed in Pakistan at both the national and international level. The Directorate is comprised of two units: (1) the Transfer of Technology and Human Resources Development Unit (TTRDU), and (2) the Agro-Industrial Consultancy Unit (AICSU). There is also an agribusiness Cell within the Ministry of Food, Agriculture and Livestock in Islamabad that 
Table 4

Public Research Institution Collaboration and Support

\begin{tabular}{|c|c|c|c|}
\hline \multirow[b]{2}{*}{ Agribusiness Category } & \multicolumn{3}{|c|}{ Number of Private Sector Firms With } \\
\hline & No Contact & $\begin{array}{c}\text { Some } \\
\text { Collaboration }\end{array}$ & $\begin{array}{c}\text { Active Support } \\
\text { and Collaboration }\end{array}$ \\
\hline \multicolumn{4}{|l|}{ A. Firms Providing Agricultural Inputs } \\
\hline \multicolumn{4}{|l|}{ 1. Multinational Firms } \\
\hline Agricultural Machinery & 1 & - & - \\
\hline Fertiliser & - & - & 3 \\
\hline Pesticide & - & 1 & 2 \\
\hline Seed & - & - & 2 \\
\hline Tobacco & - & 1 & 1 \\
\hline Sub-Total & 1 & 2 & 8 \\
\hline Percent & $9 \%$ & $18 \%$ & $73 \%$ \\
\hline \multicolumn{4}{|l|}{ 2. National Firms } \\
\hline Agricultural Machinery & 30 & 3 & 1 \\
\hline Fertiliser & - & 1 & 1 \\
\hline Poultry/Livestock Feed & 1 & 2 & 2 \\
\hline Poultry & 2 & 2 & 2 \\
\hline Pesticides & 2 & 6 & 4 \\
\hline Planting Material/Tissue Culture & 1 & - & - \\
\hline Seed & 16 & 7 & 3 \\
\hline Sub-total & 52 & 21 & 13 \\
\hline Percent & $60 \%$ & $24 \%$ & $15 \%$ \\
\hline \multicolumn{4}{|c|}{ B. Agricultural Product Processing Firms } \\
\hline \multicolumn{4}{|l|}{ 1. Multinational Firms } \\
\hline Dairy and Dairy Products & - & - & 1 \\
\hline \multicolumn{4}{|l|}{ Tobacco $^{a}$} \\
\hline \multicolumn{4}{|l|}{ 2. National Firms } \\
\hline Dairy and Dairy Products & - & 2 & - \\
\hline Food Processing & 16 & 2 & 4 \\
\hline Herbal Medicines & - & 1 & 1 \\
\hline Maize Products & - & 2 & - \\
\hline Sugar & 12 & 3 & 2 \\
\hline Solvent Oil Extractor & 5 & - & - \\
\hline Vegetable Ghee & 11 & - & - \\
\hline Sub-total & 44 & 10 & 7 \\
\hline Percent & $72 \%$ & $16 \%$ & $12 \%$ \\
\hline Total & 97 & 33 & 29 \\
\hline Percent & $61 \%$ & $21 \%$ & $18 \%$ \\
\hline
\end{tabular}

\footnotetext{
${ }^{\mathrm{a}}$ Included under Tobacco Companies in A.1.
} 
promotes agribusiness. Both the Agribusiness Directorate within PARC and the Agribusiness Cell in the Ministry have a varied history of fluctuating fortunes with the changing interest of the incumbent Secretary of Agriculture and the PARC Chairman.

\section{Incentives and Major Constraints to Research}

A question was asked if government policies and regulations provided incentives for private sector research. The unanimous answer was "No". No special government policies existed for tax relief to firms that did agricultural research. Most costly research equipment was to be imported. High ad valorem duties existed on all imported laboratory and field equipment. And there was no differentiation between import duties on research equipment and production machinery.

A question was asked about major constraints to research. The questionnaire suggested three possible constraints: (1) inability to find trained personnel, (2) financial constraints, and (3) official regulations and policies. All multinational firms avoided answering that question whereas 75 percent of all national firms answered (Table 5). Of

Table 5

Private Sector Research Constraints of National Firms

\begin{tabular}{|c|c|c|c|c|}
\hline Agribusiness Category & $\begin{array}{l}\text { Number of } \\
\text { Firms } \\
\text { Responding } \\
\text { to Question }\end{array}$ & $\begin{array}{c}\text { Trained } \\
\text { Manpower }\end{array}$ & $\begin{array}{c}\text { Financial } \\
\text { Constraints }\end{array}$ & $\begin{array}{c}\text { Official } \\
\text { Regula- } \\
\text { tions and } \\
\text { Policies }\end{array}$ \\
\hline & & \multicolumn{3}{|c|}{ (Number of Firms) } \\
\hline \multicolumn{5}{|c|}{$\begin{array}{l}\text { A. National Firms Providing Agricultural } \\
\text { Inputs }\end{array}$} \\
\hline Agricultural Machinery & 34 & - & 31 & - \\
\hline Fertiliser & 0 & - & - & - \\
\hline Poultry/Livestock Feed & 5 & - & 5 & - \\
\hline Poultry & 6 & - & 6 & - \\
\hline Pesticides & 10 & - & 8 & 8 \\
\hline Planting Material/Tissue Culture & 1 & 1 & - & - \\
\hline Seed & 23 & - & 20 & 7 \\
\hline Sub-total & 79 & 1 & 70 & 15 \\
\hline \multicolumn{5}{|c|}{ B. National Agricultural Processing Firms } \\
\hline Dairy and Dairy Products & 2 & - & 2 & - \\
\hline Food Processing & 22 & - & 22 & 10 \\
\hline Herbal Medicines & 0 & - & - & - \\
\hline Maize Products & 0 & - & - & - \\
\hline Sugar & 0 & - & - & - \\
\hline Solvent Oil Extractor & 5 & - & 5 & - \\
\hline Vegetable Ghee & 11 & - & 11 & - \\
\hline Sub-total & 57 & 0 & 40 & 10 \\
\hline Total & 119 & 1 & 110 & 25 \\
\hline
\end{tabular}


the national firms, fertiliser, herbal medicines, and maize products did not respond. Follow up contact suggested that multinational firms did not want to discuss those questions openly. Since multinational firms financing was linked to head offices abroad, there was reluctance to discuss financial matters. Also, questions about official regulations and government policies were rarely voiced openly by multinational firms.

Out of the 119 respondents, only the planting material/tissue culture firms indicated that they had problems finding trained personnel. In all but these relatively new areas Pakistan produced a good number of quality MSc. and B.Sc. graduates. Ninety-two percent of those that responded indicated that they had financial constraints that hampered their research effort. Most of these companies indicated that they could not procure credit at reasonable rates for developing their business or to undertake research. Twenty-one percent indicated that official regulations and policies were a constraint to their research effort. The respondents were pesticide, seed and food processing firms. It was not certain if the companies were responding to direct constraints that hampered research or a general complaint about rules and regulations that pertained to their business. Many seed firms did not like the strict regulations on testing and certifying seed and many pesticide companies felt that the Agricultural Pesticide Ordinance Act regulating adulteration standards and generic products was too strict.

\section{STRUCTURE AND RESEARCH INVESTMENT IN SELECTED AGRICULTURAL INPUT INDUSTRIES}

This section gives an overview of public and private sector investment in input industries and hights the problems faced by them: The first subsection reviews the seed industry followed by the fertiliser industry in the second subsection. Plant protection industry is discussed in the third subsection.

\section{The Seed Industry}

\section{Public Sector}

Pakistan had no formal seed industry up until the late sixties. Provincial agricultural departments began producing wheat, rice and cotton seed on private and public farms during the first part of the Green Revolution period. The present public sector seed industry organisation owes its origins to the 1976 Pakistan Seed Industry Project initiated by the FAO/IBRD. The objectives were release of new varieties, seed multiplication, processing, certification, storage, and marketing [Ahmad and Chaudhri (1994); Alam and Saleemi (1996)]. Under the Seed Act of 1976, the regulatory, registration and certification functions were under the Federal Ministry of Food and Agriculture. The new act initially ignored a role for the private sector and set up a public sector seed industry. The Punjab Seed Corporation (PSC) and the 
Sindh Seed Corporation (SSC) were established for seed procurement and import, production, storage and distribution in the respective provinces. The establishment of similar corporations in the North West Frontier Province (NWFP) and Balochistan was not considered economically viable; the seed demand in these two provinces could be supplied by the PSC and SSC. The NWFP Agricultural Development Authority (ADA) and the Balochistan Department of Agriculture had the mandate to meet their seed requirements through import and procurement from the Seed Corporations of Punjab and Sindh.

In the Punjab, for example, pre-basic seed is produced at the public sector research institutes and multiplied at PSC farms to obtain basic seed [Ahmad and Chaudhri (1994); Alam and Saleemi (1996)]. PSC then contracts the growing of basic seed with registered farmers to obtain certified seed. Seed quality and control is administered by the Federal Seed Certification Department (FSCD). Seed is then sold and distributed through both public and private organisations. The Punjab Agricultural Development and Supplies Corporation (PAD\&SC), a sister parastatal which sells both fertiliser and seed, markets about 60 percent of the PSC seed. PAD\&SC has its own sales depots but also sells through private dealers. The remaining 40 percent is sold by PSC through its own outlets and through private sector outlets. At the beginning of each sale season, the agents are asked by PSC to indicate their anticipated demand. Seed pricing by PSC is based on the recovery of the cost to PSC plus a margin for overheads. The PSC and ADA no longer receive direct government subsidies but SSC still does. However, indirect subsidies exist in all provinces in the form of government farms used for seed replication.

The performance of the seed corporations has not been upto the mark as was first anticipated although the PSC has had some success. The SSC has had problems with organisation and management and has not done as well as the PSC. Table 6 presents the estimated seed requirements for Pakistan and the actual seed distribution. Certified seed is made available for the major crops of wheat, cotton, rice, maize, and at times for gram and potato. Certified seed for vegetables, spice crops, oilseeds, and other pulses are not available through PSC or SSC. The 1991-92 figures in Table 6 are indicative of previous and more recent years. Although 100 percent provision seed requirements for all crops was never aimed at, it was anticipated that 75 percent requirements of high-yielding varieties of cereal crops would be met [Alam and Saleemi (1996)]. Table 6 indicates that they have fallen far short of their earlier targets. This is despite the fact that, in the Punjab, PSC seed sales are tied to PAD\&SC fertiliser sales. It has also been realised that PSC and SSC cannot fulfil the mandate to supply seed to NWFP and Balochistan as supplying their own needs takes precedence and also, because of different growing and agroecological conditions, the seed supplied by PSC and SSC is not always appropriate. 
Table 6

Seed Requirement and Distribution by Public Sector Seed Corporations, Pakistan

\begin{tabular}{|c|c|c|c|c|}
\hline Commodity & $\begin{array}{c}\text { 1991-92 } \\
\text { Estimated } \\
\text { Total } \\
\text { Requirement }^{\mathrm{a}} \\
\end{array}$ & $\begin{array}{c}\text { 1991-92 } \\
\text { Annual } \\
\text { Requirement }^{\mathrm{b}}\end{array}$ & $\begin{array}{c}\text { 1991-92 } \\
\text { Actual } \\
\text { Quantity } \\
\text { Distributed }\end{array}$ & $\begin{array}{c}\text { Percent of } \\
\text { Annual } \\
\text { Requirement } \\
\text { Satisfied } \\
\end{array}$ \\
\hline & (000’ tons) & (000' tons) & (000' tons) & $(\%)$ \\
\hline Wheat & 691.3 & 138.3 & 51.4 & 37.2 \\
\hline Cotton & 76.8 & 76.8 & 15.3 & 19.9 \\
\hline Rice & 36.7 & 7.3 & 1.9 & 26.0 \\
\hline Maize & 32.2 & 10.7 & 0.9 & 0.08 \\
\hline Gram (Chickpea) & 35.3 & 7.1 & 0.0 & 0.0 \\
\hline
\end{tabular}

Source: Ahmad and Chaudhri (1994).

${ }^{a}$ Estimated total seed requirement for all four Provinces (if seed replaced every year).

${ }^{\mathrm{b}}$ Assumes wheat, rice, and gram seed replaced by farmers every five years, cotton every year, and maize every three years.

Both PSC and SSC have the capacity to procure and distribute more seed. For example, PSC and SSC together have the capacity to double wheat seed distribution. However, several problems have prevented them from doing this [Mellor (1994), p. 252; Alam and Saleemi (1996)]. Problems include a conservative management style, poor coordination, delay in shipments to dealers, limited storage capacity in certain areas, and poor packaging material. A PSC survey indicated that 51 percent of the farmers did not use PSC seed because it was not available. Another survey indicated that 83 percent of farmers sampled in the Punjab were satisfied with the quality of wheat seed and cotton seed was reported to be of very high quality [Alam and Saleemi (1996)].

\section{Private Sector}

The Rafhan Maize Products company in the 1960s was one of the earliest private sector companies to enter the seed business. They developed hybrid maize varieties for contract growers for Rafhan's starch manufacturing business. Cargill Pakistan Seeds (Pvt.) Limited entered in 1984 and activities involved variety trials of maize, wheat, soybean and safflower hybrids. Among other early entrants were Jaffer Brothers (Pvt.) Seed Division working on seed potato and Bukhari Corporation working on cotton seed [see Alam and Saleemi (1996); Ahmad (1987); Pray (1987)] for a history of the seed industry. The seed industry invests about Rs 25.6 million today in research related activities (from Table 6) which is about 1.8 times the Rs 14.4 million (in 1998 Rupees) invested in 1987 [from Ahmad (1987)]. Investment by 
national seed firms on research is about one-third higher than investment by multinational firms.

In 1987, there were eleven registered seed companies [Ahmad (1987)]. Alam and Saleemi (1996) list over 80 registered national seed companies that existed in 1995 but the total has risen to 159 today; 150 in the Punjab, six in Sindh, two in NWFP and one in Balochistan. The Federal Seed Department has 40 more candidate seed companies under scrutiny. The national seed companies have organised themselves under two chambers; the Chamber of Private Seed Industry is the larger and is located in Multan and the other is organised under the auspices of progressive farmer businessmen in Rahim Yar Khan in Southern Punjab. Most companies, however, have ceased or never began operation and not all companies certify their seed. Two of the more prominent national seed companies are Jalundur Seed Corporation and Zaheerabad Seed Corporation who have established seed processing facilities and carry out research on scientific lines [Alam and Saleemi (1996)]. With the exception of one firm in NWFP, which has produced an indigenous sunflower hybrid, all remaining national seed companies are engaged in marketing openpollinated seed of public sector bred varieties of field crops and imported seed vegetable crops. Although companies must conform to truth-in-labelling regulations, however, many national companies import seeds and sell them directly to farmers without testing or registration.

In 1995 there were five main multinational firms registered as seed companies; Cargill, Pioneer, Sandoz, ICI Pakistan and Lever Brothers [Alam and Saleemi (1996)]. Cargill has by far the major share of the market followed by ICI and Pioneer. Cargill works on maize, sunflower, forage sorghum, wheat, rice and cotton, ICI works on maize and sunflower hybrids, and Pioneer works on maize, sunflower and forage sorghum. Sandoz did a limited amount of research and Lever Brothers has terminated its activities. A merger between Sandoz and Ciba Giegy has formed a new firm called "Novartis" but the seed division has yet to become fully operative. Another new company "AgrEvo" is getting ready to come into the business and is the result of a merger between Hoechst and Russul Uclof. Cargill Pakistan along with its subsidiaries is in the process of being taken over by Monsanto.

All multinational companies must, by law, register for seed certification. All imported plant material must be tested in Pakistan before importing large quantities. No control exists over the pricing of seed and it is determined by the free market but must conform to truth-in-labelling standards.

Multinational seed companies mostly develop hybrids of sunflowers, maize and fodder crops. Some firms market public sector bred open-pollinated varieties but are limited by the absence of Plant Breeders Rights legislation. Public sector activities dominate the wheat and rice seed market making it difficult for both national and multinational companies to compete. One of the most profitable areas is 
now in developing cotton seed varieties because of the leaf curl virus problems and recommendations that farmers change their seed each year.

The impact of the private seed industry on Pakistan agriculture is still relatively small. Many multinational firms have developed superior hybrid maize and sunflower varieties that double or even triple the yield of varieties now being used by most Pakistani farmers. However, the amount of seed made available for use by farmers is still limited. Alam and Saleemi (1996) estimate that in 1995, private national seed companies provided 3-4 percent of wheat seed requirements and less than one percent of the rice seed requirement of the entire Punjab. Multinational seed companies provided from 1-2 percent of the wheat seed, about 1 percent of the rice seed and about 3-4 percent of the maize seed requirement of the Punjab. No estimates exist for cotton and other seeds but they are in a similar category to wheat, rice and maize. However, the potential is great. Taking into consideration Pakistan's seed requirements and the amount of seed being distributed by both the public sector (Table 6) and the private sector, there is considerable scope for private sector seed companies in the future.

However, there remain several constraints to overcome before the full potential is realised. Apart from political and economic instability, other factors exist which hamper an increase in private sector seed research and development. These include policies that have favoured the public sector over the private in terms of duty free imports of seed processing equipment, provision of state land and farms for seed multiplication, donor agency funding of research and human resources which in the eyes of the private sector add up to a subsidy which they do not get. Private seed companies pay 25 percent customs duty on the import value price of seed and in-bred lines (vegetable seed exempt). There is no tax holiday for the seed industry, it pays duty on the import of processing plants and spare parts and pays local taxes on the movement of seed. There is lack of enforcement of truth-in-labelling regulations, indiscriminate imports of seed by unregistered seed companies, and a lack of awareness among farmers of the importance of good quality seed [see Alam and Saleemi (1996) and Mellor (1994), Vol. I \& II] for a further litany of problems and constraints]. Of the 23 national seed firms that responded to the survey question on major constraints to research (Table 5), 87 percent said they had financial constraints and 30 percent said that official regulations and policies were a constraint.

\section{The Fertiliser Industry}

Commercial chemical fertiliser was first used in Pakistan in 1952-53 with a gift of 1,000 tons of nitrogenous fertiliser from the USA. But the existing varieties of wheat and rice were prone to lodging with high fertiliser use and it was not until the Green Revolution high-yielding varieties arrived in the 1960s that fertiliser use became widespread. A subsidy on fertiliser also helped increase fertiliser use. 
Farmers used 6.6 thousand nutrient tons in 1955-56 which steadily increased to a peak of 2,508 thousand nutrient tons in 1995-96 but has since declined to 2,032 thousand nutrient tons in 1997-98 [Pakistan (1997)]. In 1997-98, 446 thousand nutrient tons (22 percent) was imported. Pakistan produces most of its nitrogen fertiliser needs but imports phosphatic and potassic fertilisers.

Both the public and private sectors are involved in fertiliser production and research. Public sector activities began with the Lyallpur Chemicals and Fertiliser (Pvt.) Ltd. plant in 1957 and the Pak-American fertiliser plant in 1958 followed by several joint ventures such as Pak-Arab, Pak-Saudi and Pak-China fertiliser plants [see Ahmad (1987), Table IV-2]. A Pak-Jordan DAP plant near Karachi is the latest and will be complete by the end of 1998 . The first private sector plant was built by EXXON in 1968. Two other private sector fertiliser plants followed; Dawood Hercules Chemicals Ltd. (in 1971) and Fauji Fertilisers Co. Ltd. (in 1978). All the private sector plants produce only urea.

In the 1970s privatisation period, restrictions were put on private company fertiliser sales. In 1973, the government established the National Fertiliser Corporation of Pakistan Ltd. (NFC) to take over the fertiliser manufacturing facilities of the then state owned fertiliser plants. In addition to fertiliser plants, the NFC operates the Fertiliser Research and Development Institute, a Technical Training Institute, and a National Fertiliser Marketing subsidiary. Restrictions have been taken off private sector fertiliser sales, the fertiliser subsidy to farmers has been abolished, and the NFC operates as an autonomous body that competes with the private sector. About 65 percent of the fertiliser production capacity is held by the private sector. Eight agencies market fertilisers at present, five public agencies and three private sector agencies represented by each private sector company, each having its own designated area and dealers at the local level [Mellor (1994)]. There is widespread adulteration and under weighing of fertiliser at the local dealer level and black market prices charged when some fertilisers are in short-supply. Imports must be sanctioned by the government through the Directorate of Fertiliser Imports in MINFA and at times the bureaucratic procedures result in delays of fertiliser imports making them late for the sowing period.

Early research by both public and private sectors concentrated on fertiliser response curve estimation with improved wheat, rice, maize and sugarcane varieties, on fertiliser application methods, and demonstration trials [Pray (1987)]. Public research on fertilisers and soils is currently undertaken by NARC and the provinces. Private sector research includes agronomic fertiliser trials on most prominent crops to develop fertiliser application recommendations, fertiliser formulations and blending recommendations, and soil and water analyses. The impact on increased production of fertiliser use in combination with irrigation and high-yielding varieties of wheat, rice and maize is well documented and, in part, owes some of this success to fertiliser 
related research. Salary and operating research expenditures on private sector fertiliser research in 1987 was about Rs 11.3 million (in 1998 rupees). This compares to an expenditure of Rs 26.64 million in 1998 (Table 3). The private sector continues to actively collaborate with public sector researchers (Table 4) and conduct and support trials with public research institutions and agricultural universities. Both multinational and national fertiliser firms declined to answer the question on constraints to research (Table 5).

\section{The Plant Protection Industry}

Plant protection in Pakistan is centred around the use of pesticides. Herbicides are not widely used - most farmers use weeds as a source of fodder and family labour for weeding is currently inexpensive relative to herbicides. There is some use of Integrated Pest Management (IPM) using biological control on mango, apple and sugarcane but this technology is still in the early stages of development in Pakistan and not widespread.

The pesticide industry is almost exclusively in the private sector. The public sector provides facilities for pest scouting, advisory services and aerial spraying for locusts. Pesticides are both locally produced and imported and marketed by private sector firms. The multinational firms and many national firms have their own field and extension staff. Local production of pesticides was 19,757 tonnes in 1995-96 matched by imports of 17,447 tonnes [Pakistan (1997)]. Close to 80 percent of pesticides are used on the cotton crop and the remainder on sugarcane, rice and fruits and vegetables [Mellor (1994)].

The pesticide industry became active in 1980 when the government deregulated and privatised the industry. The government announced a New Agricultural Policy that included the withdrawal of the subsidy on pesticides, transferred importing and distribution of pesticides to the private sector, discontinued free aerial spraying, and encouraged the local formulation and manufacturing of pesticides [Ahmad (1987)]. The most active multinationals to invest in Pakistan are Hoechst, Ciba-Giegy, Dow Chemicals, Pacific, Chemdyes (Bayers), Sandoz, ICI, FMC and Burmah Shell.

The pesticide industry is regulated by the Agricultural Pesticide Ordinance and Act of 1973 and prescribes heavy fines and punishment of one year minimum and three years maximum for adulterated pesticide products or for generic pesticide products that do not conform to strict regulations. These regulations are enforced more aggressively than other government rules and regulations because most of the pesticides are used on the cotton crop which is the largest single commodity foreign exchange earner for Pakistan.

Research in plant protection is done by both the public and private sectors. Public sector research at NARC and the provinces include entomology, weed 
sciences and IPM research. IPM biological control research is also done by PARCIIBC, Rawalpindi and is affiliated with CAB International in England. There are concerns that high and indiscriminate pesticide use has disturbed the natural balance of pests and parasites. In particular, the problem of the cotton leaf curl virus and its white fly vector may have stemmed from this. Plant breeding, new agronomic practices, and IPM using biological control methods has been a priority research area over the last five years in the attempt to combat the leaf curl virus.

Private sector research on plant protection is mostly in the area of pesticide use and is largely adaptive type research. In the first instance, research is done to ascertain the suitability of the pesticide, application techniques, and the collection of economic data which is the requirement under the law for the registering of a brand name and formulation. Many small local companies stop research th this point but some local and most multinationals maintain a research programme gathering additional agronomic and IPM data that feeds into product development and demonstration.

The Ahmad (1987) survey estimated expenditures on private sector pesticide research in 1987 to be about Rs 26.5 million (in 1998 rupees). This compares to an expenditure of Rs 41.2 million in 1998 (Table 3). Multinational firms spend almost twice as much as national firms. The private sector continues to actively collaborate with public sector researchers (Table 4). Eighty percent of the respondents to the question on constraints indicated they had both financial and official regulations and policy constraints to undertaking further research (Table 5).

The impact on Pakistan's agriculture production from pesticide use is considerable. The production of the hybrid Spring maize crop would not be possible without some form of plant protection use. A combination of the hybrid variety and appropriate pesticide use has enabled Spring maize yields to increase six fold over traditional maize varieties and farm practices. Chemical control of pyrilla in sugarcane is assessed to have increased raw sugarcane yield by 10 percent and sugar recovery by at least one percent. Average per hectare yield of horticultural crops has increased by 72 percent in the past ten years and the cotton crop has doubled production since the 1980 s and the use of plant protection measures, mainly pesticides, is credited for a large portion of this increase. Similarly, the average yield of Virginia Tobacco has increased from 1,957 kg per hectare in 1987-88 to 2,300 kg per hectare in 1997-98 largely due to pesticide use [Pakistan Tobacco Board (1998)].

\section{CONCLUDING COMMENTS}

Pakistan has made great strides in the past 10 to 15 years to encourage private sector investment in the country in general and in agricultural input and processing industries in particular. Private sector investment in agricultural research has more than doubled in the last ten years. Although the agribusiness research component is 
still relatively small, the potential for private sector investment in the agribusiness input and processing industries and accompanying research and development opportunities appear to be substantial. The seed, plant protection, and poultry sectors alone offer numerous opportunities for investment expansion and research. Opportunities for the food processing industries could also be substantial given an effective demand from a growing and increasingly urbanised younger population.

However, private sector investment firms seek political, economic and financial stability within a country, transparent and appropriate rules and regulations, and the consistent and fair enforcement of these rules and regulations along with the ability to profit from their investment. None of these conditions have been entirely met over the past 10 to 15 years in Pakistan. This has held back private sector investment which in turn has kept private sector agricultural research at a low level. Private sector firms do accept risk but where risk is high, firms will only do the shortterm adaptive research necessary to keep themselves in the market. Little long-term applied research will be done and it is unlikely that much basic research will be undertaken.

Given the possible decline in long-term agricultural productivity, the projected food deficit problems that may occur in the next decade, and the declining state of public sector agricultural research investment, private sector research must be encouraged to reach its full potential. This can only be done by decreasing the risk and uncertainty within the environment in which private sector firms operate. This paper has given an overview of private sector agricultural research and through the review has identified some of the constraints and problems that private sector research faces. Each agribusiness sector is unique, has its own constraints, and requires its own particular rules and regulations and solutions. Many of the solutions to the technical problems have been documented elsewhere. While it will never be possible to eradicate risk, both the government and the private sector must work together in those areas where it is possible to make a difference.

The first area where a difference can be made is by the passing of the intellectual property rights legislation. This has to be seen as a prerequisite for any further development in the seed and new plant material research area. The second major area where a difference can be made is the enforcement of all rules and regulations pertaining to intellectual property rights, patents, certification procedures, truth-in-labelling regulations and in any of the other regulation areas that make for a better agribusiness and research environment. Private sector investment and research needs a transparent set of enforced rules within which to operate. A third area lies in ensuring that private sector agricultural research operates efficiently and on a level playing field relative to public sector agricultural research and non-agricultural private sector research. A review of current local, provincial, and federal tax policies, research equipment and spare parts import duty policies, custom duties on 
imported seed and in-bred lines, and regulations regarding research in general is required.

A fourth area for consideration is fostering further and closer cooperation between private sector research and the public sector research system. Pakistan's agricultural research agenda needs both the private and public sectors to operate efficiently and in collaboration. The private sector cannot solve all the research problems on its own and there must be a balanced investment among basic, applied, and adaptive research. The private and public sectors must invest in those research areas where they have a comparative advantage but must also identify areas where research inputs would be complementary. Some mechanisms exist to foster closer cooperation between the public and private research sectors but this needs to be strengthened and made more formal. Agricultural research priorities have been identified [Nagy and Quddus (1998 and 1998a)] and there needs to be a forum (sponsored by the Government) where information is shared and a consensus arrived at on the issues of comparative advantage and complementary research.

As for the future, as research techniques become more sophisticated and private firms attempt more applied research, there will be a need for more and higher qualified scientists and support staff. Thus, there will be a need for closer ties with universities and technical schools to ensure that the appropriate number and type of qualified staff and scientists are being trained and made available.

While political and financial stability is always a concern, the above suggested areas can make a difference and decrease some of the risk and uncertainty. This would be an encouragement to the private sector to continue and expand their research agenda. Further research on private sector agricultural research itself could be in the shape of more in-depth studies of individual industries. Further independent in-depth research on research constraint identification and possible solutions to particular problems that can be brought to the notice of government is needed. There is also a need to identify mechanisms for more formal collaboration among government, the public sector, and the private sector.

\section{REFERENCES}

Ahmad, Mumtaz (1987) Agricultural Research in Pakistan's Private Sector. Management of Agricultural Research and Technology Project. The Pakistan Agricultural Research Council, Islamabad and the USAID Mission to Pakistan, Islamabad.

Ahmad, S. I., and M. Y. Chaudhri (1994) Seed Research, Production and Availability to Farmers. In Institutional Reforms to Accelerate Irrigated Agriculture. Volumes I and II. Washington D.C.: Mellor Associates.

Alam, Zahur, and A. R. Saleemi (1996) Seed Regulatory Frameworks in Pakistan. Islamabad: Enterprise and Development Consulting (Pvt.) Ltd. (EDC). 
Mellor Associates (1994) Institutional Reforms to Accelerate Irrigated Agriculture. Volumes I and II. Washington D.C.

Nagy, J. G., and M. A. Quddus (1998) National Agricultural Commodity Research Priorities for Pakistan. Agricultural Economics 19: 327-340.

Nagy, J. G., and M. A. Quddus (1998a) The Pakistan Agricultural Research System: Present Status and Future Agenda. The Pakistan Development Review 37:2 167187.

Pakistan Tobacco Board (1998) Annual Tobacco Statistics. Islamabad.

Pakistan, Government of (1997) Economic Survey. Islamabad: Finance Division, Economic Advisor's Wing.

PARC (1997) National Master Agricultural Research Plan. Pakistan Agricultural Research Council, Ministry for Food and Agriculture, Islamabad.

Pray, C. E. (1987) Private Sector Research and Technology Transfer in Pakistan. Department of Agricultural Economics, Cook College, Rutgers University. New Jersey Agricultural Experiment Station. P-02001-1-87.

Pray, C. E., and K. Fuglie (1999) The Private Sector and International Agricultural Technology Transfer in Developing Countries: Case Studies of China, India, Indonesia, Malaysia, Pakistan, the Philippines, and Thailand. USDA, Washington, D.C.

Rosegrant, M. W., M. Agcaoili, and N. D. Perez (1995) Global Food Projections to 2020: Implications for Investment. International Food Policy Research Institute, Washington, D. C. (Food, Agriculture, and the Environment Discussion Paper No. 5.) World Bank (1994) Pakistan: A Strategy for Sustainable Agricultural Growth. Agricultural Operations Division, South Asia Region. (Report No. 13092-PAK.) 